\title{
X-ray Nanospectroscopic Research with Scanning Transmission X-ray Microscopy Kanta $\mathrm{ONO}^{* 1}$
}

${ }^{* 1}$ High Energy Accelerator Research Organization (KEK), 1-1 Oho, Tsukuba-shi, Ibaraki 305-0801, Japan

(Received September 29, 2016, Accepted October 15, 2016)

\begin{abstract}
Scanning transmission $\mathrm{x}$-ray microscopy (STXM) is a unique measurement technique to perform nanoscale $\mathrm{x}$-ray spectroscopy. In this review, we briefly introduce soft x-ray spectroscopy and microscopy technique, and also describe recent results on magnetic imaging and nanoscale $\mathrm{x}$-ray circular dichroism spectroscopy on magnetic materials using STXM.
\end{abstract}

\section{1. はじめに}

軟 X 線は一般的には波長が約 $0.1 \mathrm{~nm}$ 数 $10 \mathrm{~nm}$ の電磁波 のことを指しており，物質中の電子との相互作用が強いた め, 物質に対する透過力は弱いが, 物質の化学状態 ·電子状 態の観測に適している1 . 物質中の化学状態や電子状態を知 ることは物性発現機構や化学反応機構の解明など基礎研究に とって重要であるだけでなく, 高精度の分析技術として新し い機能を持った材料やデバイスの開発などにも必要不可欠な 技術となっている. 近年では特に局所的な化学状態 - 電子状 態をナノスケールで観察することへのニーズが高まっており $\mathrm{X}$ 線顕微鏡を利用した顕微分光研究が盛んに行われている.

本稿では軟 X 線を用いて物質中の化学状態 · 電子状態を 局所的に観測する方法を紹介する. 特に軟 X 線領域の顕微 分光手法として優れた走査型透過 X 線顕微鏡（Scanning transmission X-ray microscopy : STXM）を取り上げ，原理 から実験装置, 応用例について簡単に述べる. 走査型透過 $\mathrm{X}$ 線顕微鏡により物質中の電子状態 - 化学状態 · 磁気状態 を10ナノメートル程度の高い空間分解能で可視化すること が可能になっており, 物質科学のみならず環境科学や生命科 学などの広い分野で用いられている.

\section{2. 軟 $\mathbf{X}$ 線領域での $\mathbf{X}$ 線吸収分光と $\mathbf{X}$ 線磁気円 二色性}

軟 X 線と物質との相互作用は主に光電子放出とそれに伴 う X 線吸収, また弾性散乱である。高いエネルギーの X 線 と異なり非弾性散乱やコンプトン散乱などの影響は小さい. 軟 $\mathrm{X}$ 線領域では弾性散乱は X 線吸収に比べ, 引き起こされ る確率が低いため, 主として用いられる手法は光電子分光お よび $\mathrm{X}$ 線吸収分光実験である. また, 軟 $\mathrm{X}$ 線領域では可視 光と比べて界面での屈折が大きくないため, 粒界などでの屈 折を考慮する必要はなく, 軟 X 線を用いたイメージングで は界面や粒界を持つ試料についても明瞭なコントラストを得 ることができる。

軟 X 線と物質との相互作用を定量的に表すには X 線吸収

*1 高エネルギー加速器研究機構（テ305-0801 茨城県つくば市大 穂 1-1)
係数を用いると分かりやすい。均一な物質中を透過する X 線による吸収および位相シフトは, 波長（光のエネルギー） に依存した複素屈折率 $\mathrm{n}$ で表される.

$$
\mathrm{n}=1-\delta-\mathrm{i} \beta
$$

ここで $\delta, \beta$ はそれぞれ物質の吸収と位相シフトを示して おり, i は虚数単位である.

吸収の強さは通常 Lambert-Beer の法則

$$
\mathrm{I}=I_{0} e^{-\mu t}
$$

によって表される吸収係数 (吸光度) $\mu$ を用いて, 波長 $\lambda$ に 㧤いて

$$
\mu=\frac{4 \pi \beta}{\lambda}
$$

となる・

また, $\mu$ はX 線吸収断面積 $\sigma$ と原子数密度（単位体積あ たりの原子数） $\rho_{\mathrm{a}}$ の積として表すことが出来る.

$\mathrm{X}$ 線吸収分光は $\mathrm{X}$ 線のエネルギー変化に対して $\mathrm{X}$ 線吸収 係数の変化を計測する手法である. X 線吸収分光のデータ から構造や化学状態・電子状態に関する様々な情報が得られ る. 磁気モーメントに関する情報を得るためには, 偏光 $\mathrm{X}$ 線を用いた X 線磁気円二色性や X 線磁気線二色性という現 象を利用する. X 線磁気円二色性 $(\mathrm{XMCD}), \mathrm{X}$ 線磁気線二 色性を用いることにより，磁性体の磁気モーメントに関する 定量的な情報について元素を分けて求めることが可能である.

ここで, $\mathrm{X}$ 線吸収分光の原理と円偏光 $\mathrm{X}$ 線を用いた $\mathrm{XMCD}$ の原理について $3 \mathrm{~d}$ 遷移金属を例として説明する.

まず，偏光を用いない場合(無偏光)について考えてみる. $3 \mathrm{~d}$ 遷移金属の $2 \mathrm{p} \rightarrow 3 \mathrm{~d} \mathrm{X}$ 線吸収スペクトルでは $\mathrm{Fe}, \mathrm{Co}, \mathrm{Ni}$, $\mathrm{Cu}$ の順にスペクトルのピーク強度が一定の割合で減少する ことが知られている.この現象は, 強度総和則と呼ばれる重 要な法則を示して抢り，Fig. 1 (a)に示すように $3 \mathrm{~d}$ 遷移金 属の場合 $\mathrm{L}_{3}$ と $\mathrm{L}_{2}$ 吸収強度の和は, フェルミ準位より上の $\mathrm{d}$ 状態の数, すなわち d バンドのホールの数に比例している.

強磁性体では磁気モーメントはマジョリティスピンとマイ ノリティスピンそれぞれのホールの数の差と定義できるた め, スピンに依存する X 線吸収過程が存在すれば, X 線吸 


\section{(a) Number of holes}

(b) Spin moment

(c) Orbital moment

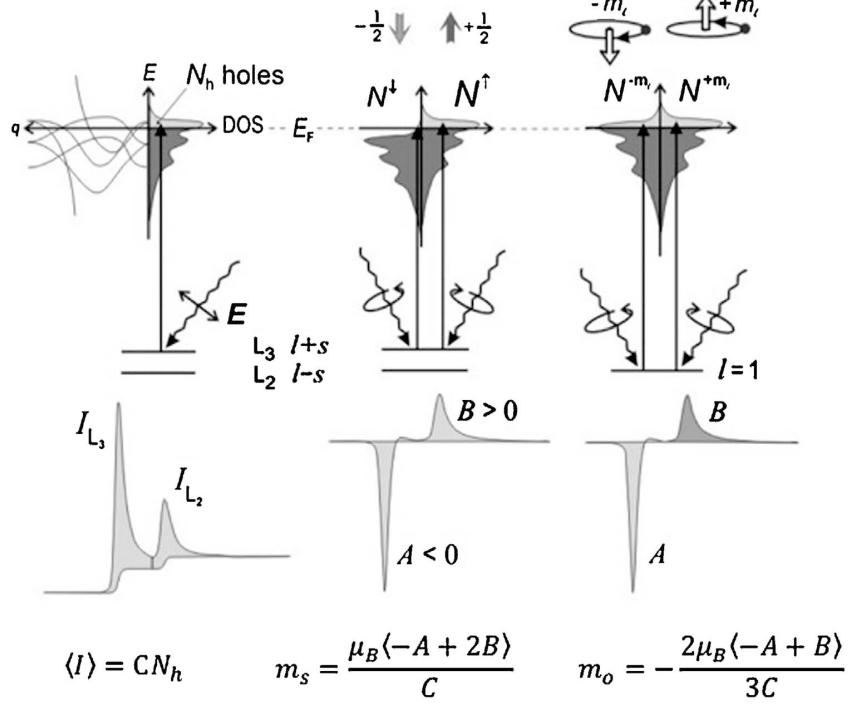

Fig. 1 Schematic diagram of optical sum rules for (a) number of holes, (b) spin magnetic moment, and (c) orbital magnetic moment.

収強度から磁気モーメントを実験的に求めることが出来ると 考えられる。

スピンに依存するX $\mathrm{X}$ 線吸収過程の観測のため円偏光 X 線 を用いた手法を XMCD と呼ぶ.

XMCD の大きさが最大となるのは, 試料の磁化 $\mathbf{M}$ の方向 と X 線の進行方向が平行あるいは反平行になる場合であり, $\mathrm{XMCD}$ 強度とは正と負のヘリシティを持つ円偏光 $\mathrm{X}$ 線に対 する $2 \mathrm{p} \rightarrow 3 \mathrm{~d}$ 吸収強度の差のことである.

光のヘリシティについて述べて扔く.X線（光子）は軌 道角運動量（光のスピンと言ってもよい）を持っており, 軌 道角運動量の向きが $\mathrm{X}$ 線の進行方向（波数 $\mathbf{k}$ ） と平行の場 合を正のヘリシティ, 反平行の場合を負のヘリシティと呼 ぶ. 右回り, 左回り円偏光という用語には定義が文献によっ て異なることもあるため, ここでは円偏光は正負のヘリシテ ィで表すことにする.

実際に観測されるXMCD の大きさは試料の磁化 $\mathbf{M}$ と入 射 X 線の進行方向 $\mathbf{k}$ との相対的な角度により, $\mathbf{M} \cdot \mathbf{k}$ に比 例したものである．また，X線の円偏光度が $100 \%$ では無い 場合, XMCD の大きさも円偏光度に比例して小さくなるた め補正する必要がある.

これらのことから, 磁気モーメントの大きさを $\mathrm{m}$, 円偏 光度を $\mathrm{P}$, 磁気モーメントと入射 $\mathrm{X}$ 線の進行方向の相対角 を $\theta$ とすると, XMCD 強度 $\mathrm{I}_{\mathrm{XMCD}}$ は,

$$
I_{\mathrm{XMCD}}=P\langle m\rangle \cos \theta
$$

と表すことが出来る.

XMCDの測定結果からスピン磁気モーメントと軌道磁気 モーメントを分離して求める方法について述べる.

XMCD 測定からスピン磁気モーメントと軌道磁気モーメ ントを分離して求めるには, 電荷, スピン, 軌道モーメント に関する 3 つの総和則を用いる.

Fig. 1 に電荷, スピン, 軌道モーメントに関する総和則の
模式図を示す.

電荷総和則はすでに述べたように, X 線吸収の平均強度 が価電子帯のホールの数 $\mathrm{N}_{\mathrm{h}}$ に比例するというものである.

電荷総和則は, $3 \mathrm{~d}$ 遷移金属以外の元素に対しても一般化 することが出来, X線励起により内殼から遷移した先の状 態の軌道角運動量を $\mathrm{L}$ とすると（例えば， $2 \mathrm{p} \rightarrow 3 \mathrm{~d}$ 吸収の場 合は $\mathrm{d}$ 軌道なので $\mathrm{L}=3,3 \mathrm{~d} \rightarrow 4 \mathrm{f}$ 吸収の場合は $\mathrm{f}$ 軌道なので $\mathrm{L}=4), \mathrm{X}$ 線吸収強度〈I $\rangle$ は, 価電子帯のホールの数 $\mathrm{N}_{\mathrm{h}}$ に比 例し，以下のように表すことが出来る.

$$
\begin{gathered}
\langle I\rangle=\mathrm{CN}_{h} \\
\mathrm{C}=\frac{(A R)^{2} L}{3(2 L+1)} \\
\mathrm{A}=4 \pi^{2} \alpha h v
\end{gathered}
$$$$
\text { ここで, }
$$

$\alpha$ は微細構造定数, $\mathrm{R}$ は遷移の動径方向の行列要素である.

スピン磁気モーメント $\mathrm{m}_{\mathrm{s}}$ を求めるには, スピン総和則と 呼ばれる以下の法則を用いる. Fig. 1(b) に示すように A, B をそれぞれ， $\mathrm{L}_{3}, \mathrm{~L}_{2}$ 吸收端での XMCD 積分強度 $\left(\mathrm{L}_{3}, \mathrm{~L}_{2}\right.$ 吸 收ピークを積分し，正と負のヘリシティに対する差をとった もの）とすると，以下の式が成り立つ.

$$
m_{s}=\frac{\mu_{B}\langle-A+2 B\rangle}{C}
$$

ここで, $\mathrm{m}_{\mathrm{s}}$ は原子あたりのスピン磁気モーメント, Cは 上述した比例定数である.

同梯にして, 軌道磁気モーメント $\mathrm{m}_{\mathrm{o}}$ を求めるためには軌 道モーメント総和則を用いる (Fig. 1(c)).

$$
m_{o}=-\frac{2 \mu_{B}\langle-A+B\rangle}{3 C}
$$

ここで， $\mathrm{m}_{\mathrm{o}}$ は原子あたりの軌道磁気モーメントである.

上述した総和則を用いることにより， $\mathrm{L}_{3}, \mathrm{~L}_{2}$ 吸収端での $\mathrm{XMCD}$ 積分強度からスピン磁気モーメントおよび軌道磁気 モーメントを分離して, 定量的に求めることが出来る.

スピン磁気モーメントと軌道磁気モーメントを独立に計測 することは他の実験手法では難しいため, 軌道磁気モーメン トが重要な役割を果たす磁気異方性の研究などに威力を発揮 する.

\section{3. 軟 $\mathbf{X}$ 線の集光}

軟 X 線を用いた顕微分光では軟 $\mathrm{X}$ 線を集光する必要があ る. 可視光の集光とは異なる軟 $X$ 線の集光光学について簡 単に説明する. 可視光領域の光学顕微鏡と異なり, 軟 X 線 領域では以下に述べるように, 凸レンズのような屈折レンズ を用いることはできない，そのため，軟 X 線の集光抢よび 結像には特殊な光学系が必要となる.

光を用いて顕微鏡観察する場合, 光は波の性質を持ち解像 の限界が回折効果の限界により決をる.これを回折限界と呼 び, 回折効果が小さくなる短い波長や大きな回折角を持つ 
(開口数の大きい) 光学系を用いれば高い空間分解能が期待 される. 軟 $\mathrm{X}$ 線の波長は $0.5 \sim 10 \mathrm{~nm}$ 程度であり，回折限界 として数 $\mathrm{nm}$ 程度の空間分解能が期待され, 現状でも 5 10 $\mathrm{nm}$ 程度の空間分解能は達成されている. 軟 $\mathrm{X}$ 線顕微分光で は, 高い空間分解能が得られることと合わせて, 軟 X 線領 域の光が物質中の電子との相互作用が大きいため, 物質の電 子状態, それぞれの元素の吸収端を利用した化学状態, 磁気 円二色性を用いた磁気状態の観察などに適している.

これらの特徵を利用して有機化合物をはじめとして軽元素 が含まれる物質や磁性材料などで軟 X 線を用いた顕微分光 研究が盛んに行われている.

可視光の集光技術を波長の短い軟 $\mathrm{X}$ 線に適用することは 難しい，軟 $\mathrm{X}$ 線を含む $\mathrm{X}$ 線領域で効率のよいミラーや屈折 レンズなどの光学素子を設計し作製することが極めて困難で あるのが原因である. 軟 $\mathrm{X}$ 線領域では軟 $\mathrm{X}$ 線は通常物質中 を数 $10 \mu \mathrm{m}$ から数 $100 \mathrm{~nm}$ 程度しか進むことができない。こ のため, 光学顕微鏡などで一般的に用いられている透過型レ ンズを軟 X 線は透過することができず集光光学素子として 用いることが出来ない.

ミラーによる光学系は, 軟 X 線領域での反射率が一般的 に低いため，それが高くなる斜入射条件で用いなければなら ない.このため，ミラーでは十分な開口数を得ることができ ず，回折限界集光は困難である.

ゾーンプレートは Fig. 2 に示すような環状の形状の回折 格子であり, その刻線密度は中心から外側に行くに従って大 きくなっており，外側と内側に照射された光が焦点距離で一 点に集光するようになっている ${ }^{2)}$. 通常のゾーンプレートで は金属でできた同じ幅の輪帯が薄いメンブレン上に作製され ている.ゾーンプレートは図に示すように，N 個の輪帯と 透明な部分で構成されて抢り, $\mathrm{n}$ 番目の透明部分から集光点 までの距離を $\mathrm{d}_{\mathrm{n}}$ としたときに， $\mathrm{n}+1$ 番目の透明部分から集 光点屯での距離が $\mathrm{d}_{\mathrm{n}}+\mathrm{m} \lambda$ となるようになっている.ここで, $\mathrm{m}$ は回折の次数, $\lambda$ は波長である.このため, 異なる輪帯か らの光が互いに干渉し, $\mathrm{f}_{\mathrm{m}}$ に $\mathrm{m}$ 次の焦点を結ぶ.この条件 を満たすためのゾーンプレートの $\mathrm{n}$ 番目の輪帯の半径 $\mathrm{r}_{\mathrm{n}}$ は 以下のように表すことができる.

$$
r_{n}=\sqrt{m n \lambda f m+\frac{(m n \lambda)^{2}}{4}}
$$

通常, 焦点距離は波長と比べて十分に長くなる.

$$
f_{m} \gg \frac{m n \lambda}{4}
$$
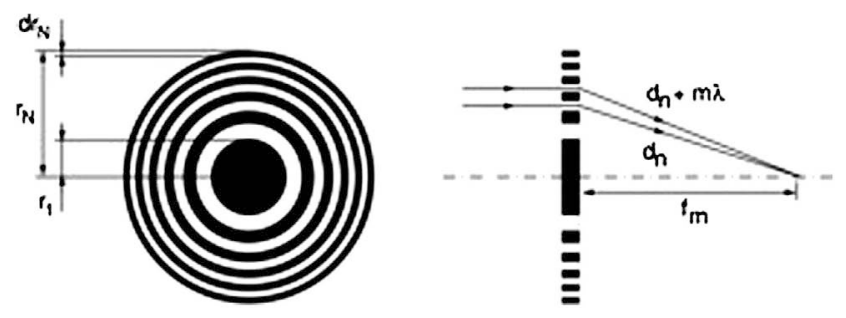

Fig. 2 Schematic diagram of a Fresnel zone plate.
ため, 第 2 項の球面収差の項は無視することができる.

このため, 焦点距離 $\mathrm{f}_{\mathrm{m}}$ は次のように表すことができる.

$$
f_{m}=\frac{r_{n}^{2}}{m n \lambda}=\frac{r_{N}^{2}}{m N \lambda}
$$

このように, 焦点距離は波長に依存していることが分か る.このため, ゾーンプレートを用いる場合には波長に応じ てゾーンプレートと試料との位置を調整しなければならない.

ここで，上式についてNの式と N-1の式の差をとるこ とにより, 次式を得る.

$$
\Delta r_{N}=\frac{\lambda f}{2 r_{N}}=\frac{r_{N}}{2 N}
$$

ここで

$$
\Delta r_{N}=r_{N}-r_{N-1}
$$

である。

ゾーンプレートにより得られる回折限界の集光サイズ（空 間分解能）を考えてみる.レーリーの定義で空間分解能 $\delta$ は，

$$
\delta=\frac{0.61 \lambda}{\mathrm{NA}}
$$

と表される.

$$
\text { ゾーンプレートの開口数 NA は }
$$

$$
\mathrm{NA}=\frac{r_{N}}{f}=\frac{m \lambda}{2 \Delta r_{N}}
$$

であるから，

$$
\delta=1.22 \Delta \mathrm{r}_{\mathrm{N}} / \mathrm{m}
$$

となり, 空間分解能が最外の輪帯の幅で決まっていることが 分かる。

ゾーンプレートの集光サイズは上記で決まる回折限界と幾 何光学的な集光サイズにより決まる. 回折限界の集光のため には，ゾーンプレート全体が空間的にコヒーレントに照明さ れる必要がある.ここでコヒーレントとは同一光源から発し た 2 つ光が光の進行方向に垂直な面内で干渉可能である ことをいう.すなわちゾーンプレート上の任意の 2 点を取 ったときに，仮想光源点からの光が干渉可能であることを意 味している.ゾーンプレート全体が空間的にコヒーレントに 照明されない場合には, 空間的にコヒーレントに照明されて いる領域に対応する回折限界で集光サイズが制限される。こ れは幾何学的な集光サイズが回折限界より大きくなっている ことを意味している．軟 X 線領域では，高輝度放射光源を 使うことでゾーンプレートを空間的にコヒーレントに照明す ることが可能であるため, 回折限界集光サイズを得ることが 出来る. 第 3 世代放射光では偏向電磁石ビームラインでも 十分なコヒーレンスが得られるが，第 2 世代放射光では十 分なコヒーレンスを得るために，アンジュレータビームライ ンを利用することが一般的である。

集光にゾーンプレートを用いる場合には, 不要な次数の回 
折光を取り除くため, OSA (order sorting aperture) と呼ば れるピンホールをゾーンプレートの下流側に設置する必要が ある。

ゾーンプレートでは空間分解能を高くする（開口を大きく する）には最外の輪帯の幅をなるべく小さくする必要があ る.このため, ゾーンプレート光学系を用いた軟 X 線顕微 鏡では, 高い空間分解能を得るために重要なことは, 最外輪 帯幅の小さいゾーンプレートを作製することである. しかし ながら, 光学顕微鏡並みの開口数を得るためには輪帯幅を波 長程度まで小さくする必要があり, 現状のナノ加工技術では $10 \mathrm{~nm}$ 程度の輪帯幅が限界である.

最先端のナノ加工技術を駆使して，2つのゾーンプレート を重ねることにより輪帯幅を半分にして高い空間分解能を目 指す試みや，原子層積層を行うことにより $10 \mathrm{~nm}$ 以下の空間 分解能が達成され始めている.

\section{4. 軟 $\mathbf{X}$ 線顕微分光}

軟 $\mathrm{X}$ 線のエネルギーを変化させてイメージングを行う と, 局所領域での X 線吸収スペクトル測定が可能になる. ここでは走査型透過 X 線顕微鏡 $(\mathrm{STXM})$ を用いた軟 X 線 顕微分光について紹介する4).

STXM は，X線を集光し試料上に照射し，試料を走査す ることでイメージングおよび顕微分光を行う手法である. STXM の模式図をFig. 3 に示す. STXM では, ゾーンプ レートによりX線を集光し, 試料を走査しながら, 試料を 透過した X 線強度を X 線検出器により測定する.このよう にして，試料の実空間像を得ることができる. STXM は走 査型の手法であるため, リアルタイムでのイメージングには 向かないものの，X線を試料の所望の位置に自由に照射で きるため, 局所領域の X 線吸収スペクトルの測定など顕微 分光測定を行う場合には有利である.

STXM では試料上での X 線照射量が透過 X 線顕微鏡より 1 桁程度弱いため, X 線による放射線損傷を受けやすい試料 に対してはSTXMの方が適している。これは有機物や生体 物質など放射線によるダメージが顕著な物質を分析する上で は重要である．金属材料や無機材料では現実的には X 線照 射による試料ダメージはほとんどないためあまり考慮する必 要はない. STXM では通常のイメージングの他に, 2 次元 検出器を利用して, 試料の微小スポットからの回折像を取得

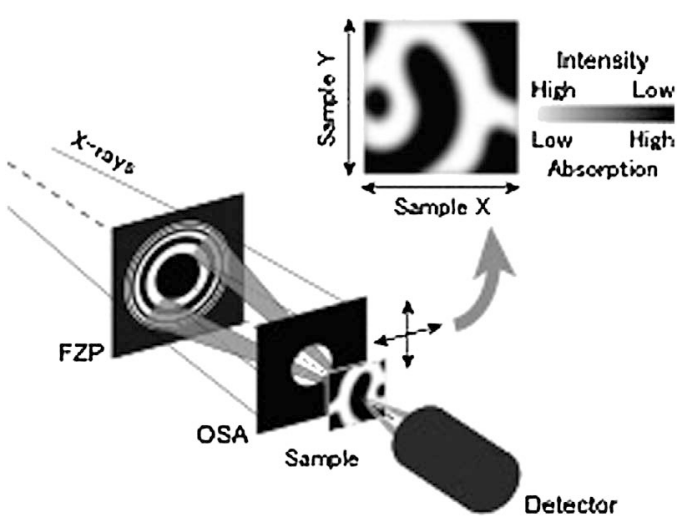

Fig. 3 Schematic diagram of STXM.
することにより，X線が試料を透過したときの位相変化に 起因する位相コントラストのイメージを得ることも可能であ る. 位相変化が大きくなる波長は X 線吸収が最大となる波 長とは異なって抢り，試料への放射線損傷が少ないことも利 点である. また, 最近では STXM とコヒーレントX 線回折 とを組み合わせたタイコグラフィという手法の研究が盛んに 行われている. タイコグラフィでは，試料上の X 線スポッ トを走査しながら各点でのコヒーレント X 線回折像を取得 する. 通常のコヒーレントX 線回折では, 位相問題のため 画像の再構成が一般的には困難であるが，タイコグラフィで は，試料を走査するときに各測定点の間に重なりを持たせて おり，これらの情報を反復的に解析することにより実空間像 が得られる.この手法では, 2 次元検出器を用いて回折像を 得ていることから, 十分な開口数（散乱べクトルの大きさ） が得られる.ただ，高い散乱べクトル領域では計数率が小さ いため, 検出器のノイズと計数率により空間分解能が決まっ ている. X 線領域での小さい開口数の問題が緩和されてお り，近い将来は軟 $\mathrm{X}$ 線顕微分光研究の標準的なツールにな ることが期待される.

\section{5. 走査型軟 $X$ 線透過顕微鏡（STXM）}

走査型の顕微鏡である走査型軟 X 線透過顕微鏡 (STXM) では，Fig. 3 に示すようにゾーンプレートを用いてX線を 試料上に微小スポットとして集光し，試料スキャンを行うこ とによってイメージを得る。すなわち, 空間分解能は X 線 のスポットサイズによって決をる. STXMでは，高い空間 分解能を達成するためには, 空間的にコヒーレントに照明す ることが必要であり，このため輝度の高い光源としてアンジ ェレータからの放射光を用いることが多い，最近では，放射 光リングの高輝度化が進み, 新しい放射光施設では偏光電磁 石からの放射光を用いても高い性能が得られている.ここで は，われわれの開発したSTXM を例に実験装置を説明する.

磁性材料観察が可能な STXM 装置はこれまで国内には存 在しなかったため, 磁性材料の STXM 観察は海外で行う必 要があった. 高精度の磁性材料観察を国内で行うことは磁性 材料の研究開発にとって契緊の課題であると考え, われわれ は従来の装置に比べ極めてコンパクトで安定性の高い STXM 装置開発を行った3)。われわれが開発したSTXM 装 置では高精度エンコーダを搭載したピエゾ駆動ステージを採 用し，さらに装置を全てデジタル制御することにより，全体 を極めてコンパクトにすることが出来た．その結果，既存の 軟 $\mathrm{X}$ 線放射光ビームラインに設置が可能な可搬性など従来 の装置に比べて極めてコンパクトであることを実現したのみ ならず，FZPの回折限界で決まる高い空間分解能や床振動 に対する安定性，レーザ干渉計を用いた試料位置制御による 長時間測定についての安定性など世界最高水準の $\mathrm{X}$ 線顕微 鏡性能を両立することに成功した。この装置は現在高エネル ギー加速器研究機構フォトンファクトリーのビームライン $\mathrm{BL}-13 \mathrm{~A}$ に設置され，250-1600 eVの軟 X線を用いた STXM 実験に用いられている.

Fig. 4 に示すようにフォトンファクトリーの BL-13 アン ジュレータからの放射光を分光器により単色化し, STXM 


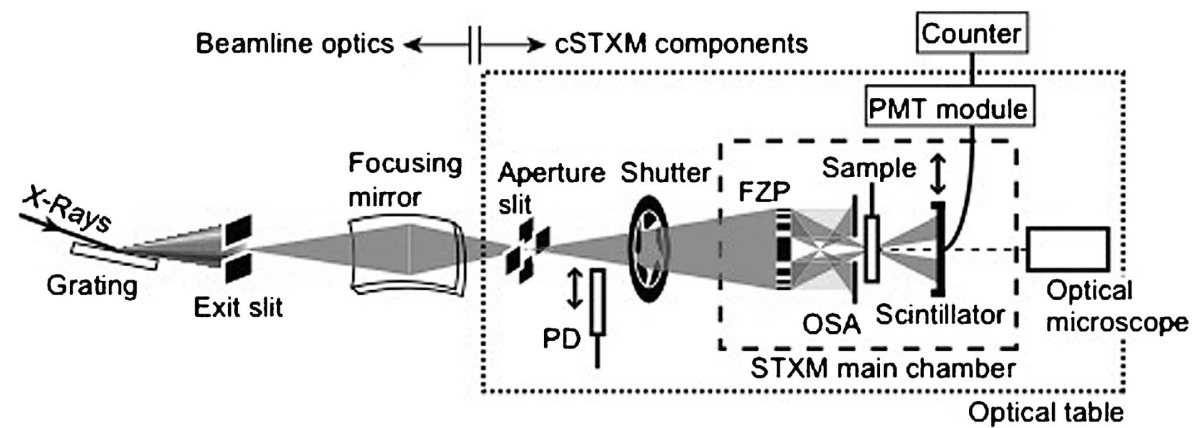

Fig. 4 Schematic diagram of the STXM system installed at BL-13 of the Photon Factory.

に用いている.ビームラインの集光点にアパーチャスリット を設置し，ビームサイズを数 $10 \mu \mathrm{m}$ に制限している．このよ うにすることで, 既存のビームラインに取り付け可能な STXM 装置を実現している，このスリット位置を仮想光源 点とすることにより，ゾーンプレート焦点位置で数 $10 \mathrm{~nm} の$ スポットサイズを達成している，回折されないX線を取り 除くためには, ゾーンプレートの半分程度の大きさのビーム ストップを用いる. また，希望する次数の回折光（通常は一 次）のみを取り出すために，ゾーンプレート下流には OSA (order sorting aperture) と呼ばれるピンホールが設置され ている. 図中のシャッターは測定時以外に試料に軟 X 線が 照射されるのを避けるため用いる．Fig. 5 に示すように STXM 装置は非常にコンパクトでフットプリントが A4 サ イズ程度の真空槽に設置されている．実験はへリウム置換䨌 囲気で行われることが多いが，真空での実験や，真空空を用 いることによって試料を大気圧に保持したままでの測定も可 能である.

試料の位置決めは, 粗動の $\mathrm{X}-\mathrm{Y}-\mathrm{Z}$ 軸ピエゾステージを用 いており, 光学エンコーダにより $50 \mathrm{~nm}$ 程度の精度で大きな 範囲（数 $\mathrm{cm} ）$ の粗動を行うことが出来る。 また， X-Z 軸の ピエゾスキャナを用いて $\mathrm{nm}$ 以下の精度で数 $\mu \mathrm{m}$ の範囲につ いて試料走査を行う。ピエゾ素子は印加電圧に対し, 非線形 性およびヒステリシス性を持つため，スキャン精度を確保す るためには位置のフィードバックを行わなければならない. フィードバックのために用いられる位置センサとしては，一 般的には静電容量センサやレーザ干渉計が用いられている. われわれはレーザ干渉計を用いたサブ $\mathrm{nm}$ の位置精度での位 置読み取りとフィードフォワードおよびフィードバックによ るピエゾ制御を組み合わせた超精密位置決めを行っている. 通常の PC を用いた制御では STXM 実験に必要なリアルタ イム性を確保できないため，われわれは制御システムをプロ グラム可能な集積回路である FPGA (field-programmable gate array）上に実装し，実験に用いている。このため，従 来の STXM 装置に比べ，X線のエネルギーを変えたときの 試料位置の精度などが飛躍的に向上しており，軟 X 線顕微 分光研究を行う上で極めて有用なシステムとなっている. 試 料スキャンステージの下流側には大口径の高効率 $\mathrm{X}$ 線検出 器を置き, 透過した X 線強度の測定を行う。よく用いられ る検出器としては, 気体を用いた比例計数管, 蛍光スクリー ンと光電子増倍管, シリコン検出器などであり, 高い $\mathrm{X}$ 線 検出感度々高い計数率の両方が求められる.われわれの

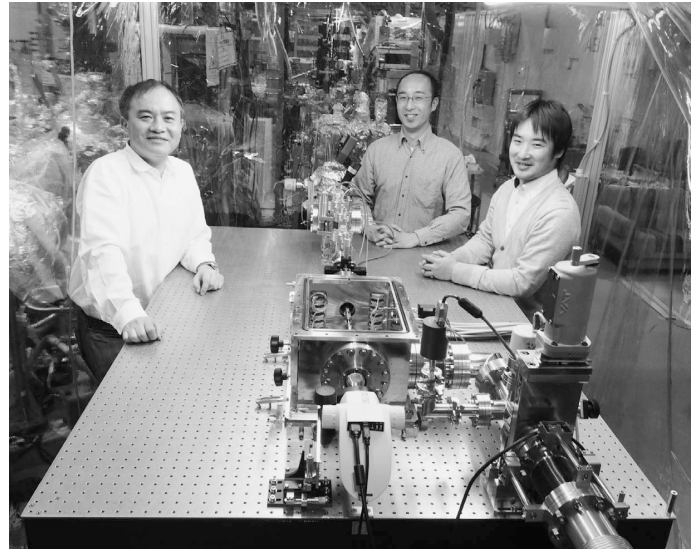

Fig. 5 Picture of the STXM system installed at BL-13 of the Photon Factory.

STXM 装置では，独自に開発したシンチレータで軟 X 線を 可視光変換し, 光ファイバで真空槽の外へ転送し, 大気側で 計数するシステムを開発して用いている．このような独自開 発のシステムを利用することにより，非常に高精度での顕微 分光研究が可能となった.

実験を行う際には位置測定機能の付いた光学顕微鏡により 試料位置を確認し，目的の場所にSTXM の粗動ステージで 移動するか，STXM 装置の試料ホルダ部分を直接光学顕微 鏡で観察できるセットアップになっている.

\section{6. 走査型軟 X 線透過顕微鏡を用いた研究例}

STXM 装置を用いた研究例として，STXM を用いた永久 磁石材料の磁気イメージングについて紹介する ${ }^{5-7)}$.

$(\mathrm{Nd}, \mathrm{Dy})-\mathrm{Fe}-\mathrm{B}$ 磁石はハイブリッド車や電気自動車の モータに用いられており，Dyの低減が課題となっている. Dyの果たす役割を明らかにするためには, 元素識別した磁 気イメージングは特に有効な手法である.

STXM 観察をするためには試料を数 10 ～100 nm 程度の薄 片にする必要がある。このため，( $\mathrm{Nd}, \mathrm{Dy})-\mathrm{Fe}-\mathrm{B}$ 磁石から $50 \mathrm{~nm}$ 程度の厚さの薄片を切り出し, 実験を行った. 希土類 元素が含まれている材料は酸化されやすいため, 薄片試料が 酸化されないように十分に気をつける必要がある.

STXM 実験では，それぞれの構成元素の化学マッピング および元素識別した磁気イメージングを行い，元素分布と磁 気構造との相関を調べることが可能である．そこで， $(\mathrm{Nd}$, Dy)-Fe-B 磁石について, Fe L-吸収端, Nd M-吸収端, 


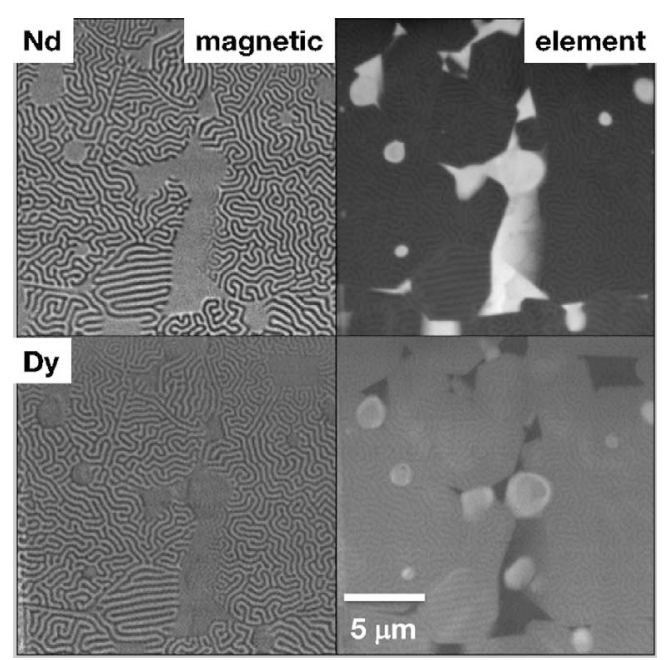

Fig. 6 Element specific chemical maps and magnetic images of $(\mathrm{Nd}, \mathrm{Dy})-\mathrm{Fe}-\mathrm{B}$ permanent magnets.

Dy M-吸収端でそれぞれ化学マッピングと磁気イメージン グを行った. STXM では, 局所領域でのX 線吸収分光測定 も可能であるので, 元素識別した化学マッピングのみなら ず，化学結合状態を識別することも可能である．この手法に より，例えば遷移金属元素や希土類元素が含まれている材料 について，金属状態あるいは価数の異なる状態の空間分布を 観察することが出来る.

Fig. 6 に熱消磁状態の ( $\mathrm{Nd}, \mathrm{Dy})-\mathrm{Fe}-\mathrm{B}$ 磁石の化学マップ と元素識別磁気イメージを示す. 磁気コントラストは $\mathrm{X}$ 線 磁気円二色性によるものであり，白と黒の領域はそれぞれ磁 化の向きが $\mathrm{X}$ 線の入射方向（試料面と垂直方向）と平行お よび反平行であることを示している．空間分解能は $15 ２ 0$ $\mathrm{nm}$ 程度である. 数 $100 \mathrm{~nm}$ の幅を持った迷路状磁区が明瞭 に観察できていることが分かる，得られた元素識別磁気イ メージから, Nd と Fe の磁気イメージは同じ白黒のコント ラストであるが，Dyと Feの磁気コントラストは白黒反転 していることが分かる．このことは， $\mathrm{Fe}-\mathrm{Nd}$ が強磁性的な 相互作用を示すのに対し，Fe-Dy では反強磁性的相互作用 により，全体の磁化が減少していることを示している。 た，化学マップから Dy が多く含まれている場所（白いコン トラスト）が分かる，その領域では磁区幅が大きくなってい る.これは Dy が多く含まれる領域で結晶磁気異方性が大き くなっていることを示しており，Dyが含まれる磁石の保磁 力が高くなることを表している，また，磁区幅が異なる境界 で磁区は連続的につながっている。これは，Dy含有量の違 う結晶粒の間が磁気的に分断されていないことを示してい る.このように, STXMによる磁気イメージングでは, 通 常のバルクの磁気特性評価からは得られない局所情報が得ら れ，電子顕微鏡などでの組織構造情報と組久合わせること で，材料組織と材料特性の相関をミクロに解明することが可 能になる. また，局所観察手法としては定性的な磁気・化学 コントラストだけではなく, 定量的な磁気モーメントや磁気 エネルギーを測定することが可能であり, 磁性材料研究にお いて非常に強力なツールとなっており, 次世代の磁性材料開 発の進展へつながることが期待されている。

STXM では上述した化学・電子状態・磁気イメージング
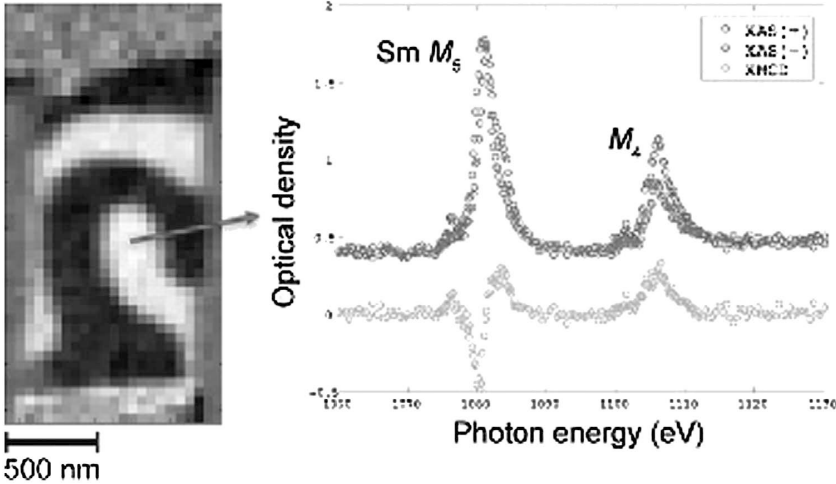

Fig. 7 Magnetic images and nanoscale XMCD spectra of $\mathrm{SmCo5}$ permanent magnet.

の他に，局所的な X 線吸収分光測定も可能である.このよ うな顕微 X 線分光技術は磁性材料をはじめとする材料研究 や宇宙地球科学, 環境科学分野の研究に極めて有用である. その一例として STXM により得られた局所 XMCD スペク トルを Fig. 7 に示す。図では永久磁石材料である $\mathrm{SmCo5}$ の磁気イメージと XMCD スペクトルを示している．XMCD スペクトルは図の丸で囲んだ部分の 1 ピクセルでの XMCD スペクトルを抽出したものである. 1 ピクセルのサイズは40 $\mathrm{nm}$ であり，測定時間は各点で 10 ミリ秒である。通常の XMCD 測定と比べて極めて小さい領域で測定したスペクト ルであるが，短い計測時間で $\mathrm{S} / \mathrm{N}$ の良いスペクトルが得ら れていることが分かる，このように，磁気イメージを測定す るだけではなく, 各点で X 線吸収スペクトルや XMCD スペ クトルが得られることが，この実験手法の大きな強みとなっ ている.

これまで見てきたように，STXM は軽元素や磁性体の化 学状態, 電子状態, 磁気状態を明らかにする上で極めて重要 な手法である．今後は X 線顕微分光に対するニーズが産業 界をはじめとしてさまざまな分野から寄せられることが期待 される．実験手法を洗練するだけでなく，実験データから定 量的な物理量を抽出するなどデータ解析の高度化も今後の課 題である.

\section{〔文献〕}

1) D. T. Attwood: Soft X-rays and Extreme Ultraviolet Radiation: Principles and Applications (Cambridge University Press, Cambridge, 1999).

2) M. Howells, C. Jaconbsen and T. Warwick: Principles and Applications of Zone Plate X-Ray Microscopes, Science of Microscopy (Springer, New York, 2007).

3) K. Ono: Magnetic Imaging Handbook (in Japanese) (Kyoritsu Shuppan, Tokyo, 2010).

4) Y. Takeichi, N. Inami, H. Suga, C. Miyamoto, T. Ueno, K. Mase, Y. Takahashi and K. Ono: Rev. Sci. Instrum., 87 (2016) 013704 .

5) K. Ono, T. Araki, M. Yano, N. Miyamoto, T. Shoji, A. Kato, A. Manabe, H. Nozaki, Y. Kaneko and J. Raabe: IEEE Trans. Mag., 47 (2011) 2672.

6) K. Ono, T. Araki, M. Yano and N. Miyamoto: Materia, 50 (2011) 379.

7) M. Yano, K. Ono, T. Araki, A. Manabe, T. Shoji and A. Kato: TOYOTA Technical Review, 60 (2014) 77. 